\title{
Entre riscos e rabiscos: questões de crítica genética na teatralização de A Pedra do Reinopor Antunes Filho ${ }^{1}$
}

Lucimara de Andrade

\section{A querela entre encenador e dramaturgo}

O Grupo de Teatro Macunaíma, coordenado por Antunes Filho, logo após a montagem de Nelson Rodrigues, o eterno retorno, cogitou adaptar para o teatro Grande sertão: veredas, porém desviou-se para o Romance d'A Pedra do Reino de Ariano Suassuna. Alteração de rota que se explica, segundo Sebastião Milaré, "pela densidade mítica da obra de Suassuna" ${ }^{2}$, e ainda, segundo o autor, porque "o romance de Suassuna contém o manancial arquetípico que Antunes procurava. Entretecido de imagens do inconsciente e de fatos históricos, é o campo perfeito para as pesquisas do CPT."

Antunes pretendia estrear o espetáculo no início dos anos 1980. No entanto, a peça teatral, que recebeu o nome de A Pedra do Reino, só estreou em 20 de julho de 2006, no Teatro Anchieta em São Paulo. Ariano, a princípio, não concordava que a adaptação fosse feita, por "cisma" dele com determinadas passagens da obra. Em entrevista ao programa Metrópolis da TV Cultura de 15 de junho 2007, Ariano Suassuna esclarece: "quando eu vi a adaptação de Antunes ele tinha incorporado quase como coisa principal a segunda parte ${ }^{5}$ que eu não aceitava mais."

Vejamos esse importante depoimento de Ilka Marinho de Andrade Zanotto:

lembro-me pouco de minha gestão pró-Antunes, sei que voltei a São Paulo com dois exemplares do Dez sonetos com mote-alheio, um para o diretor. Houve interrupção de alguns anos, durante os quais autor e diretor trocaram cartas e acertaram ponteiros. Finalmente, por mãos de Romero Andrade Lima chega-me uma carta na qual Suassuna concordava com o

\footnotetext{
${ }^{1}$ Este artigo é uma adaptação do segundo capítulo de minha tese intitulada Pelo viés da teatralização: A Pedra do Reino por Antunes Filho. A tese está disponível no endereço: https://repositorio.ufmg.br/handle/1843/LETR-AMHG8D. Nela é possível ter acesso às fotografias das correspondências e a trechos dos manuscritos.

${ }^{2}$ MILARÉ, Sebastião. Hierofania: o teatro segundo Antunes Filho. São Paulo: Edições SESCSP, 2010, p. 88.

${ }^{3}$ Ibidem, p. 90.

${ }^{4}$ Ariano Suassuna pretendia escrever uma trilogia chamada A Maravilhosa Desaventura de Quaderna, o Decifrador e A Demanda Novelosa do Reino do Sertão. Como A Pedra do Reino, o segundo livro teria cinco partes, das quais ele escreveu apenas duas e publicou no Diário de Pernambuco como folhetim. No entanto, Ariano pegou a primeira parte e publicou, em forma de livro, com o título História d'O Rei Degolado nas caatingas do sertão: ao Sol da Onça Caetana, mas depois chegou à conclusão que tinha cometido um erro, tanto é que o livro não foi reeditado: "Quaderna mudou completamente, acabou-se a ironia, porque eu deixei que a minha história pessoal entrasse pela história e pela personalidade de Quaderna. Enquanto $A$ Pedra é narrada por Quaderna, O Rei Degolado é narrado por Suassuna. Eu já tinha descoberto que era um erro, parei, não publiquei a segunda parte." (AGÊNCIA, 2006). Quando Ariano fala em "erro", ele refere-se a ter se deixado levar pela carga autobiográfica.

${ }^{5}$ Aqui Ariano se refere ao romance História d'O Rei Degolado nas caatingas do sertão: ao Sol da Onça Caetana.

${ }^{6}$ SuAssunA, Ariano Villar. São Paulo, Brasil, 15 jun. 2007. 1DVD. Entrevista concedida ao Programa Metrópolis.
} 
espetáculo de Antunes fosse como fosse feito. Era Agosto de 1988. Os contatos iniciais haviam sido interrompidos por um mal entendido entre autor e diretor. Suassuna percebera a discrepância entre o Quaderna personagem de A Pedra do Reino e aquele da História d'O Rei Degolado nas caatingas do sertão que seria, no seu entender, um alter-ego. Era-lhe insuportável assistir no palco ao drama de sua família, remexendo na chaga sempre aberta do assassinato de seu pai João Suassuna. Por falta de comunicação, Antunes enveredara pela história pessoal narrada na segunda obra e deu-se o curto-circuito.

Antunes diz que, à época, Suassuna também estava preocupado com o play-writing ausente nas adaptações "em progresso" do diretor, sendo Suassuna o autor consagrado que era de peças extraordinárias como $O$ Auto da Compadecida que já ganhara mundo. Posteriormente vieram dois filhos de Suassuna, esguios ambos e altos, ela loiríssima, assistir ao espetáculo já pronto, mas não estreado, com Marcos de Oliveira como Quaderna, para dar o nihil obstat que de fato deram. Novo curto-circuito por razões burocráticas: Antunes tinha um prazo para instaurar no SESC o seu “Teatro de repertório”, projeto que não pode ser implementado em tempo. Passam-se duas décadas. E finalmente, no palco do Anchieta o milagre acontece quando a Pedra do Reino - teatro - coloca-se à altura dos livros e como síntese estupenda de toda a cosmogonia suassunica. ${ }^{7}$

O impasse entre Ariano e Antunes nos coloca frente a discussões pertinentes do âmbito teatral tais como: a questão da autoria, o debate entre a ideia de escritura dramatúrgica e escritura cênica ${ }^{8}$, ou melhor dizendo, entre as funções do encenador e do dramaturgo e o lugar do texto. A figura do encenador, diante dos protestos do dramaturgo, reclama a autoria do espetáculo: o direito de empreender sua leitura sobre o texto. Tal embate dialoga, ou se enquadra em uma das tendências do teatro contemporâneo que é o reconhecimento do teatro como arte autônoma e não como mera ilustração da literatura.

Qual pode e deve ser, então, a tarefa do diretor? A esse questionamento, Margot Berthold ${ }^{9}$ elenca as seguintes possibilidades: a primeira resposta que vem à mente é a tradicional, ou seja, servir à obra. A segunda seria levar a obra adiante, prolongando o trabalho do autor. A terceira seria desafiar a obra. É tarefa do diretor, portanto, encontrar o ponto de vista a partir do qual poderá descobrir as raízes da criação dramática. Todavia, como esclarece a teórica, este ponto de vista não pode ser utilizado, nem escolhido arbitrariamente, pois, apenas na medida em que o diretor sinta-se como servidor e expoente de sua época, ele conseguirá fixar o modo de ver em comum com as forças cruciais que modelam a natureza de uma época.

Antunes Filho parece se aproximar mais das linhas que buscam tanto o levar a obra adiante - como observamos em sua experiência adquirida com os teleteatros que prezava por levar ao conhecimento do público

\footnotetext{
${ }^{7}$ Zanotto, Ilka Marinho de Andrade. Quaderna. Sala Preta, São Paulo, n. 6, p. 101, 2006.

${ }^{8}$ Como nos esclarece Rosiane Trotta (2006), expressão "escritura cênica”, que surge nos anos 70, reconhece por fim a arte autoral do encenador e o espetáculo como obra autônoma. No verbete de Pavis, a escritura cênica decorre de uma encenação "assumida por um criador que controla o conjunto dos sistemas cênicos, inclusive o texto, e organiza suas interações, de modo que a representação não é o subproduto do texto, mas o fundamento do sentido teatral”. (PAVIS, 2015, p.132)

${ }^{9}$ BeRThOlD, Margot. Teatro do diretor. In: História mundial do Teatro. São Paulo: Perspectiva. 2006. p. 529-539.
} 
obras consideradas culturalmente importantes - como também desafiar a obra no sentido de empreender sobre ela possibilidades de expansão através de diálogos intertextuais.

Voltemos a Ariano. Um dos questionamentos do escritor era sobre o fato de ele considerar-se como a pessoa mais apta a adaptar o Romance d'A Pedra do Reino. Alexandre Santini (2005) destaca como aspecto importante da dramaturgia de Ariano a sua intenção de vincular o texto teatral ao seu caráter espetacular, e não ao universo literário. Nesse sentido, de acordo com Santini poder-se-ia dizer que haveria

uma indissociabilidade entre a escrita dramatúrgica e a escrita cênica em que a peça não é "mero" texto dramático, mas sim, uma partitura cênica que conjuga e utiliza teatralmente a ambientação, o vestuário, a composição dos personagens e todos os mecanismos de produção de sentido na cena teatral. Certamente esse procedimento não é uma exclusividade de Suassuna, tendo sido largamente utilizado na dramaturgia contemporânea. Sua singularidade está na maneira de manipular teatralmente esses signos visando obter o efeito cômico, pela ênfase nos mecanismos de repetição (de bordões e de diálogos), o exagero na definição do caráter e das características físicas, bem como na observação das "funções sociais" e na descrição do universo social dos personagens. ${ }^{10}$

Nos textos dramáticos de Ariano, e mesmo em seus romances, percebe-se essa intenção de vincular o texto teatral a seu caráter espetacular. Na carta de Ariano Suassuna para Ilka Marinho Andrade Zanotto, de 30 de maio de 1985, e na datiloscópia Quaderna, ou A Pedra do Reino, Ariano não só sugere alterações no texto dramático como também na encenação a que ele nem chegou a assistir. Ariano solicita modificações na encenação baseado nas apreciações feitas por seus filhos. Ou seja, Ariano insere sua vontade autoral inclusive na escritura cênica que é de competência do encenador. Algo que é importante chamar a atenção é para o fato de que Ariano parece desconhecer a concepção de encenador. É como se ele ainda estivesse preso à concepção anterior que remonta ao século XIX quando o dramaturgo era a figura principal.

O conceito de autoria é movediço, principalmente quando se trata de processos de adaptação. Pois a retórica padrão costuma enaltecer o discurso da perda. O lamento do que foi "perdido" na transposição acaba por se tornar mais importante e com isso se perde a oportunidade de perceber o que foi alcançado. Com demasiada frequência o discurso sobre a adaptação ainda coloca a obra adaptada como subalterna. Nesse sentido é importante contribuir com apreciações a cerca desse debate.

\section{A ideia de texto definitivo}

Em entrevista presente em O Teatro em Pernambuco: trocando a máscara de 1994, Suassuna esclarece o porquê de não ter autorizado Antunes a levar para o palco A Pedra do Reino na década de 1980. Segue um trecho da entrevista.

Aí, Sábato, na carta, dizia que eu não entendia bem a posição dele, que ele reivindicava essa autoria do espetáculo, que no tipo de trabalho dele os textos nunca eram os mesmos, sempre

\footnotetext{
${ }^{10}$ SANTINI, Alexandre. Teatro e cultura brasileira no século 20 - Ariano Suassuna e Movimento Armorial.in: RABETTI, Beti (Org.). Teatro e comicidades: estudos sobre Ariano Suassuna e outros ensaios. Rio de Janeiro: 7Letras, 2005. p. 65-66.
} 
mudavam. Aí, eu disse: “- Então, agora é que eu não deixo mesmo. Eu só tenho um jeito de deixar esse espetáculo: se ele me mandar o texto e eu aprovar. Se eu aprovar, esse texto tem que ser definitivo, não pode mudar mais não." ${ }^{11}$

As idas e vindas do texto revelam o processo de trabalho que o texto "definitivo", não consegue transmitir. Segundo Lebrave (2002), o texto impresso constitui uma unidade estável e bem delimitada e, da mesma forma, enquanto objeto abstrato caracteriza-se pela sua unicidade. Para o autor, "uma vez criado e posto em circulação, o texto existe por si mesmo e torna-se independente do autor que o escreveu e dos acasos de sua forma material. ${ }^{12}$ Importante destacar a consideração do teórico ao afirmar que o texto tornar-se independente do autor pelo fato de entrar em circulação. Algo bastante complicado de se pensar quando o autor ainda está vivo. Sabemos que essa alforria não é assim tão simples.

No caso de Ariano e Antunes, por exemplo, a querela aconteceu por algumas divergências conceituais. Quando menciono que Ariano e Antunes possuíam divergências conceituais é no sentido de que ambos se expressam de formas diferentes e, por isso, num primeiro momento, não foi possível uma parceria devido a individualidades, conceitos e processos artísticos que não dialogavam, pois Ariano parecia advogar a autoria também da adaptação. Por isso torna-se pertinente a discussão sobre a questão da autoria.

Philippe Willemart nos apresenta a seguinte reflexão sobre a noção de autor:

a crítica dos anos sessenta acostumou seus seguidores a festejar a morte do autor e a trabalhar com as categorias resultantes da narratologia do texto. A valorização dos manuscritos deixava entender que as noções de texto e de autor eram frágeis e deviam ser revisadas, como o constatava Louis Hay no Congresso Franco-alemão de 1983. Em um prefácio muito conciso de Languages, Almuth Grésillon e Jean-Louis Lebrave definiam o material textual como um espaço em que o autor-scriptor e o autor-leitor respondem-se em um canto constantemente alternado. O autor não é mais o escrevente que transcreve um texto inspirado, nem que se entrega à escritura esquecendo do que é constituído, nem simplesmente o sujeito da enunciação ou o sujeito do enunciado, mas, a cada leitura, retoma-se inteiramente, desdobra-se e enxerga o texto como um objeto, visto de fora, ao qual aplica um olhar crítico.

O texto relido não é, portanto, um espelho em que se admira o escrito, mas o viés através do qual se insinua um Terceiro no texto, que seja a tradição literária ou histórica, o inconsciente do autor ou outros fatores que excedem o escritor. O Terceiro ou o Outro, se retomarmos o conceito lacaniano, pouco importa de onde vem, insere-se pela leitura-escritura no texto. Diríamos até que, mesmo em caso de simples cópia de um texto, para não dizer de plágio, o autor acrescenta a sua parte. ${ }^{13}$

11 Suassuna, Ariano Villar. Entrevista sem título. In: BacCARelli, Milton. O Teatro em Pernambuco: trocando a máscara. Recife: FUNDARPE, 1994. p. 145.

12 LeBrave, Jean-Louis. Crítica genética: uma nova disciplina ou um avatar moderno da filologia? In: ZULAR, Roberto (Org.). Criação em processo: ensaios de crítica genética. São Paulo: Iluminuras, Fapesp, 2002. p. 109-110.

13 Willemart, Philippe. A rasura e a consistência. In: WILlEMART, Philippe. Universo da criação literária: crítica genética, crítica pós-moderna? São Paulo: Editora da Universidade de São Paulo, 1993. p. 67-68. 
Esse viés pelo qual se insinua o terceiro poderia ser chamado de o lugar da fissura. E são essas fissuras que, acredito, garantem o status de inacabamento de um texto. A propósito do conceito de inacabamento, Michel Butor possui uma reflexão muito pertinente para a nossa discussão. No texto "Crítica e invenção", Michel Butor declara que a obra inacabada é "para nós a necessidade de uma invenção." ${ }^{14} \mathrm{E}$ ao dissertar sobre "o fazer crítica" Butor esclarece que fazê-la é sempre considerar que o texto da qual se fala não é suficiente por si, sendo necessário acrescentar-lhe páginas. Na visão do crítico, "a obra nova é um germe que cresce no terreno da leitura e a crítica é como sua floração." 15

Haroldo de Campos em seu texto "A usurpação luciferina" observa que

\begin{abstract}
se pensarmos, como Borges, que "o conceito de texto definitivo não corresponde senão à religião ou ao cansaço" abalaremos essa substancialização idealizante do original, deslocando a questão da origem para a pergunta sempre "di-ferida" a respeito do "borrador do borrador" (posto que, segundo Borges, "pressupor que toda recombinação de elementos é obrigatoriamente inferior a seu original, é pressupor que o borrador 9 é obrigatoriamente inferior ao borrador $\mathrm{H}$ - já que não pode haver senão borradores"). Em vez de render-se ao interdito do silêncio, o tradutor-usurpador passa, por seu turno, a ameaçar o original com a ruína da origem. ${ }^{16}$
\end{abstract}

Para Haroldo de Campos, a tradução opera como uma "deslocação reconfiguradora"17. Nesse sentido, poderíamos dizer que a partir do momento em que se faz uma nova leitura de algo, ou que se transforma ou recria algo, uma nova obra nasce, pois o objeto transformado se desprende do original e ganha um novo olhar e novos contornos.

A proposta de perceber a figura de Antunes Filho como a de um tradutor-teatralizador que enxergou a possibilidade de transportar as narrativas de Ariano Suassuna para o palco traz consigo a necessidade de se refletir sobre a problemática texto-representação.

\title{
3. A problemática texto-representação
}

Para Anne Ubersfeld ${ }^{18}$ a primeira contradição que encerra a arte do teatro é a oposição texto-representação. A autora acredita que a semiologia do teatro deve considerar o conjunto do discurso teatral e não recusar a distinção texto-representação, visto que os instrumentos requeridos para a análise de um e de outro não são os mesmos. Segundo a teórica, a atitude clássica, que privilegia o texto e vê na representação apenas a expressão e a tradução do texto literário, supõe a ideia de equivalência semântica entre o texto escrito e sua representação. E tal equivalência, como esclarece Anne Ubersfeld, corre o sério risco de ser uma ilusão, pois o conjunto dos signos visuais, auditivos, musicais criados pelo encenador, decorador, músicos, atores, constitui um sentido (ou uma

\footnotetext{
${ }^{14}$ BUTOR, Michel. Crítica e Invenção. In: BUTOR, Michel. Repertório. São Paulo: Perspectiva, 1974. p. 199.

${ }^{15}$ Ibidem, p. 200.

${ }^{16}$ CAmpos, Haroldo de. In: TÁPIA, Marcelo e NóBregA Thelma Médici (Orgs.). Haroldo de Campos - Transcrição. São Paulo: Perspectiva, 2013, p. 56, grifo do autor.

${ }^{17}$ Ibidem, p. 110.

${ }^{18}$ Ubersfeld, Anne. Para ler o teatro. São Paulo: Perspectiva, 2005.
} 
pluralidade de sentidos) que vai além do conjunto textual e reciprocamente, na infinidade de estruturas virtuais e reais da mensagem (poética) do texto literário, muitas desaparecem ou não podem ser captadas, apagadas que são pelo próprio sistema da representação. Assim, para a teórica, a arte do encenador e do ator consiste, em grande parte, na escolha daquilo que "não é preciso saber ouvir". ${ }^{19}$ Pensamento que parece dialogar com o de Jean-Pierre Ryngaert, para o qual "o teatro repousa, desde sempre, sobre o jogo entre o que está escondido e o que é mostrado, sobre o risco da obscuridade que de repente faz sentido". ${ }^{20}$

Dando sequência a sua reflexão sobre a relação texto-representação, Anne Ubersfeld chama nossa atenção para a atitude que consiste em privilegiar o texto literário como o primordial. Para a autora tal atitude identificase com a ilusão de uma coincidência entre o conjunto dos signos do texto e o dos signos representados. Segundo Ubersfeld, o perigo da atitude que privilegia o texto literário como primordial reside na tentação de congelar o texto a ponto de bloquear todo o sistema da representação e a imaginação dos intérpretes, mas o maior perigo consiste em privilegiar não o texto, mas uma leitura particular do texto. Assim, "vê-se não somente como o privilégio concedido ao texto corre o risco de esterilizar o teatro, mas, também, porque é tão necessário distinguir claramente no fato-teatro, o que é característico do texto daquilo que é próprio da representação". ${ }^{21}$

Segundo Marvin Carlson ${ }^{22}$, a proposta de Anne Ubersfeld destaca-se como uma das mais amplas e ambiciosas tentativas de estudar semioticamente o texto dramático como uma base para a representação. Todavia, como salienta Carlson, Marco De Marinis contestou a abordagem de Ubersfeld ${ }^{23}$ em 1978 com a assertiva de que uma verdadeira semiótica do teatro deve afastar-se da consideração do texto como espetáculo e aproximar-se do espetáculo como texto.

Ao discorrer sobre a nova teatralogia ${ }^{24}$, que considera as obras, sejam textos ou espetáculos, a partir de um ponto de vista processual, Marco De Marinis ${ }^{25}$ aponta para o fato de que ainda permanece aberta, e muito controversa, a questão metodológica, mais especificamente as implicações metodológicas da revolução teórica dos estudos teatrais, cujo objeto foi radicalmente mudado, passando do texto dramático ao fato teatral.

Diante de tal reflexão, sobre a relação texto-representação surge um questionamento. Seria possível chamar de tradução intersemiótica o processo de teatralização? Roman Jakobson ${ }^{26}$ apresenta-nos o seguinte postulado sobre a tradução: a tradução intralingual, ou reformulação, consiste na interpretação dos signos verbais por meio

\footnotetext{
${ }^{19}$ Ibidem, p. 3.

${ }^{20}$ RYNGAERT, Jean-Pierre. Ler o teatro con temporâneo. São Paulo: Martins Fontes, 1998. p.5.

${ }^{21}$ UBERSFELD, Anne. Op. cit, p. 4, grifos da autora.

${ }^{22}$ CARLSON, Marvin. Teorias do teatro: estudo histórico-crítico, dos gregos à atualidade. São Paulo: Editora UNESP, 1997.

${ }^{23}$ Abordagem semiótica presente obra de referência Para ler o teatro, cujo título original é Lire le théâtre publicado pela primeira vez em 1977.

${ }^{24}$ Como prática científica de pesquisa, a nova teatrologia nasce na Itália, nos anos 70, dentro da nova história do teatro (Marotti, Molinari, Zorzi, Cruciani, Meldolesi e outros). Como teoria se desenvolve, mais especificamente, na segunda metade dos anos 80 , através da superação do paradigma estruturalista que se formou a partir do encontro entre história do teatro, ciências humanas e sociais e prática teatral.

${ }^{25}$ DE MARINIS, Marco. Nova teatrologia e performance studies: questões para um diálogo. Repertório: teatro \& dança, Salvador, ano 13, n. 15, p. 95-103, 2010.

${ }^{26}$ JAKOBSON, Roman. Os aspectos linguísticos da tradução. In: JAKOBSON, Roman. Linguística e comunicação. São Paulo: Cultrix, 1995. p. 63-72.
} 
de outros signos da mesma língua; a interlingual, ou tradução propriamente dita, consiste na interpretação dos signos verbais por meio de outros signos da mesma língua; já a tradução intersemiótica ou transmutação consiste na interpretação dos signos verbais por meio de sistemas de signos não verbais.

Teóricos como Haroldo de Campos e estudiosos como Julio Plaza e Claus Clüver, entre outros, ampliaram em seus estudos as discussões sobre o assunto tradução. No entanto, embora o entendimento de tradução como recriação esteja hoje, de certa forma, disseminado entre seus estudiosos, ainda há, como esclarece Marcelo Tápia ${ }^{27}$, os defensores da fidelidade em tradução como sinônimo da primazia do significado na preservação do essencial da mensagem traduzida.

Patrice Pavis esclarece que a adaptação teatral, diferentemente da tradução, goza de grande liberdade. Para o teórico todas as manobras textuais como cortes, reorganizações, abrandamentos estilísticos, concentração dramática em alguns momentos específicos, acréscimos, entre outros, são permitidas em função do discurso da encenação. ${ }^{28}$ Em diálogo com a reflexão de Pavis, essa proposta entende o processo de teatralização como um processo adaptatório que opera nas mais diversas instâncias (corte, colagem, inversão, concentração dramática, acréscimos, etc).

\section{Passagem do texto dramático para o cênico: questões de crítica genética}

Estudar os movimentos do processo permite-nos trilhar os caminhos pelos quais o artista esboçou sua obra. Os rascunhos comprovam estar o ato de criação ligado há um lento, longo e minucioso processo de pesquisa. Os documentos de processos teatrais ocupam um campo de estudos em que se intercruzam a crítica genética, a teoria da literatura e a teoria teatral. Por conseguinte, tal campo de estudos tem o mérito de trazer para reflexão conceitos operadores como rascunho, correspondências, dialogismo, intertextualidade, autoria, teatralidade, escrita e texto.

A página de rascunho, que nos coloca a par da intimidade do processo do artista revelando os recuos da escrita, os avanços, as desistências, os cortes e substituições enfim, os movimentos da obra em processo. A rasura, como pistas para a análise detetivesca do crítico, deixa transparecer todo o movimento no seu sentido mais amplo. A liberdade de rasurar, de arrepender-se e de acrescentar novas construções que de forma irregular avançam pelas margens, misturam-se entre as linhas, sobem e descem sem qualquer pudor, ora livres e tortuosas, ora entre balões ou ainda direcionadas por setas e agrupadas por asteriscos denunciam a volubilidade da criação em devir onde tudo ainda é incerteza.

Os documentos de processo $^{29}$ - no caso teatral - oferecem-nos não só o privilégio de penetrar nos bastidores do laboratório experimental de criação do artista, mas também a oportunidade de desenvolver uma pesquisa voltada para a análise de aspectos importantes do procedimento criativo como uma construção de ordem coletiva.

27 TÁPIA, Marcelo. Apresentação. In: TÁPIA, Marcelo e NÓBREgA Thelma Médici Orgs.). Haroldo de Campos Transcrição. São Paulo: Perspectiva. 2013. p. XI-XX.

${ }^{28}$ PAVIS, Patrice. Dicionário de teatro. São Paulo: Perspectiva, 2015. p. 10.

${ }^{29}$ Os documentos desse trabalho, ou como prefere dizer Cecilia Almeida Salles “documentos de processo", funcionam como suportes da memória, pois se configuram como registros materiais de um processo criador. Referência: SALLES, Cecilia Almeida. Gesto inacabado: processo de criação artística. São Paulo: FAPESP: Annablume, 1998. 
Os bastidores da criação representam, dessa maneira, um desafio e um convite ao pesquisador por tratar-se de um campo de natureza móvel. O outro desafio diz respeito ao enfrentamento da concepção que percebe a crítica genética $^{30}$ como se ela fosse destruir a literatura, ao exaltar os rascunhos, tornados "proletários oprimidos" ${ }^{\text {"1 }}$.

Tal concepção apocalíptica, todavia, evidencia mal-entendidos de ordem conceitual, pois a crítica genética é, como esclarece Hay (2007), parte integrante da crítica, com a qual ela partilha a sua razão de ser, ou seja, fazer viver a experiência da literatura em sua plenitude procurando transmitir a força da obra através do conhecimento de seu devir. ${ }^{32}$

No entanto, se por um lado há uma concepção que demoniza a investigação genética, por outro lado existe uma certa aura no pensamento que vê os autógrafos como relíquias, pelo que evocam do escritor. Mas é mister estar atento para o fato de que a crítica genética "não pode dizer o porquê das coisas. Mas ela diz - e é a única a fazê-lo - o como." ${ }^{33}$

$\mathrm{Na}$ busca pelo "como" torna-se fundamental aproximar-se dos documentos de processo como um homem que escava como Walter Benjamin reflete poeticamente em "Escavando e recordando":

quem pretende se aproximar do passado soterrado deve agir como um homem que escava. Antes de tudo, não deve temer voltar sempre ao mesmo fato, espalhá-lo como se espalha a terra, revolvê-lo como se revolve o solo. Pois - fatos nada são além de camada que apenas à exploração mais cuidadosa entregam aquilo que recompensa a escavação. [...] e certamente é útil avançar em escavações segundo planos. Mas é igualmente indispensável a enxada cautelosa e tateante na terra escura. ${ }^{34}$

E escavando e escovando eis que se descobrem os passos e os recuos do processo de construção de A Pedra do Reino de Antunes Filho. Tal fato torna-se relevante, pois se caracteriza como um dos objetos de investigação pautados nos estudos da cena teatral contemporânea, interessada nos coletivos de criação e na condução de seus projetos, dinâmicas e procedimentos.

\footnotetext{
${ }^{30}$ Segundo Louis Hay, a crítica genética surgiu no início dos anos de 1980. "O método da crítica genética destacou-se por indução de uma massa de trabalhos empíricos consagrados aos manuscritos do autor. Progressivamente, eles fizeram aparecer a aptidão desses documentos a testemunhar, sob certas condições, operações genéticas. Dessas origens, a crítica genética conserva um procedimento cujos modelos se elaboram por generalização de um conjunto de observações concretas. Quanto a seu objeto ele pode ser caracterizado pela dualidade de seu estatuto: um certo material, enquanto documento observado, é a construção intelectual enquanto processo de escritura. Na verdade, é por uma sequência regulada de operações analíticas - deciframento, restituição da cronologia, reconstrução do percurso da escrita - que, do grafismo imobilizado e fragmentado de um traço, pode-se retroceder ao movimento de uma gênese e de um pensamento."(HAY, Louis. A literatura dos escritores. Belo Horizonte: Editora UFMG, 2007. p. 41)

${ }^{31}$ Ibidem, p. 36.

${ }^{32}$ Ibidem.

${ }^{33}$ Ibidem, p. 66.

${ }^{34}$ BENJAMin, Walter. Escavando e recordando. In: Obras Escolhidas. Rua de Mão Única. São Paulo: Brasiliense, 1995. p. 239.
} 
Segundo Mencarelli $(2010)^{35}$, essa valorização do "como fazer" esteve associada à emergência do teatro de arte no final do século XIX e ganhou novos contornos ao longo das renovações cênicas do século XX e início do XXI, quando profissionais do teatro foram cada vez mais colocados em confronto na sala de ensaio. Para o autor, a emergência dos teatros laboratórios na segunda metade do século XX, associada aos princípios artaudianos, provocou sucessivas crises na busca por centralidades nos processos e foi aos poucos afirmando a tessitura das pluralidades como uma das principais tarefas criativas. Ainda segundo Mencarelli, uma percepção mais clara das múltiplas dimensões da construção do sentido na cena, levava à proposição de uma construção dramatúrgica também pensada em diferentes planos. Por conseguinte, tal processo levou ao reconhecimento de uma autonomia do texto cênico pensado como distinto do texto dramático.

\section{A rasura como testemunha e instância autoral}

O processo de construção do texto dramático de A Pedra do Reino passou por um longo percurso. Do "Resumo Borrão" da década de 1980 com 221 páginas até a versão de estreia de 2006 com 25 páginas, vários trechos foram suprimidos, acrescentados e rearranjados. Se a proposta se pautasse em analisar as rasuras ao longo do processo, num primeiro momento, seriam selecionados os documentos: o "resumo borrão", o segundo documento "em três atos" e o terceiro documento em "quatro blocos", para analisar o processo de criação da equipe de atores. Num segundo momento, seriam analisadas as rasuras de Ariano e, num terceiro momento, as rasuras de Lee Taylor, ator que representou o personagem Quaderna na teatralização de 2006. Mas isso seria material para uma tese. Assim, cabe esclarecer que aqui interessa analisar apenas as rasuras de Ariano, pois elas nos ajudarão a refletir sobre a questão autoral.

Em "A rasura e a consistência", Philippe Willemart esclarece que cada retomada do texto provoca uma "consistência nova". É na rasura que se manifesta, segundo Willemart, a "intervenção do primeiro leitor, e cada acréscimo, a contribuição de um texto lembrado, anotado, uma resposta de uma estética insciente ou não, ou um pensamento novo." ${ }^{36}$

Segundo Henri Focillon em "Elogio da mão", é através das mãos "que o homem entra em contato com a solidez do pensamento: elas, o liberam. Impõem-lhe uma forma, um contorno e, dentro da própria escrita, um estilo." ${ }^{37}$ Para o autor, as mãos podem até ser serviçais, mas são dotadas de um temperamento enérgico e livre e de uma fisionomia como "rostos sem olhos e sem voz, mas que veem e que falam." ${ }^{38}$ Por que as mãos? Que privilégio é este? Por que este órgão mudo e cego nos fala com tamanha força de persuasão como nos questiona Henri Focillon? Porque é com elas que os artistas criam. É ela que cria, e que aborta. É ela que rasura, que corta, que acrescenta, que rasga, que materializa o pensamento.

Como ler essas rasuras? Essas marcas desses documentos privados? Até que ponto elas devem ser consideradas? Como Almuth Grésillon afirma "os manuscritos nos obrigam a apreender, a levar a sério a questão

\footnotetext{
${ }^{35}$ MeNCARELli. Fernando Antonio. Dramaturgias em processo: a cena pelo avesso. In: GrUPO TEATRO INVERTIDO. Cena invertida: dramaturgias em processo. Belo Horizonte: Edições CPMT, 2010. p. 13-14

${ }^{36}$ WILlEMART, Philippe. op. cit, p. 68.

${ }^{37}$ FoCILLON, Henri. Elogio da mão. In: FoCILLON, Henri. Vida das formas. Rio de Janeiro: Zahar, 1983. p. 126.

${ }^{38}$ Ibidem.
} 
dessa instância escrevente." ${ }^{39}$ Assim sendo "os manuscritos não são apenas o lugar da gênese das obras mas também um espaço onde a questão do autor pode ser estudada sob uma nova luz: como lugar de conflitos enunciativos, como gênese do escrito." ${ }^{40}$

Nós todos que escrevemos, como esclarece Philippe Willemart, sabemos que a rasura não se define simplesmente como um risco que corrige um erro ortográfico ou sintático, que melhora o estilo e elimina uma informação. Claro que não podemos negar a presença desse tipo de rasura em manuscritos - a propósito, é a mais comum. Todavia, antes de seu efeito final de substituição e/ou eliminação, a rasura, qualquer que seja a configuração, abre um momento. Momento da intenção autoral, manifesta nos comentários, traços e cortes que encerram uma elaboração, causando uma perturbação na linearidade da escrita.

Para Pierre-Marc de Biasi, a rasura constitui um componente complexo da escritura. Segundo o autor, o sentido da rasura depende de seu suporte, de sua localização física na página, de seu objeto, de suas eventuais relações de interdependência com outras rasuras, de seu momento e de seu grau de liberdade ou de limitação. ${ }^{41}$ Com base nessa primeira exposição, Biasi propõe uma série de classificações das rasuras segundo suas eventuais funções. Porém, esclareço que nesse trabalho não há a intenção de classificar as rasuras de Ariano. Pretende-se pensar as rasuras como marca de uma vontade autoral.

Ariano recebeu, em cópia datilografada, o texto de adaptação de A Pedra do Reino para ser aprovado por ele. Tempos depois, Ariano Suassuna encaminha a Ilka Marinho Andrade Zanotto o texto revisado com o título da adaptação alterado para Quaderna, ou A Pedra do Reino. Essa alteração consta como a primeira exigência de Ariano na carta para Ilka de 30 de maio de 1985. O título escolhido anteriormente por Antunes seria Quaderna. O próprio Ariano havia sugerido a troca do título para Quaderna, o Decifrador. No entanto, Ariano aborta a própria sugestão - Quaderna, o Decifrador - para sugerir outro nome - Quaderna, ou A Pedra do Reino - para se aproximar da linha dos títulos dos folhetos de feira do Nordeste.

Ao longo de todo o documento há outras inserções que deixam claras algumas opiniões de Ariano no que concerne a questões políticas, outras que deixam claras a sua postura em relação à escritura dramática e outras em relação à execução da parte musical da encenação. E todas essas interferências seguem como uma exigência para a autorização da encenação na carta encaminhada para Ilka Marinho Andrade Zanotto, que Ariano elegeu como sua representante no diálogo com Antunes Filho.

A título de exemplo reproduzo aqui trechos de Ariano da datiloscópia Quaderna, ou A Pedra do Reino. Solicitação de acréscimos: "Ver a "Pedra do Reino" pag. 35 e 41. Sem esses dois acréscimos não tenho condições de aceitar e autorizar a encenação." (tal rasura consta no verso da capa do documento). "Meu sonho é fazer do Brasil uma ampliação de Canudos, um Reino de república-popular, com a justiça e a verdade da Esquerda e com a beleza e o sonho da Monarquia sertaneja'. Esta frase é fundamental. E não se trata de acréscimo abusivo meu, não: origina-se de outra, quase igual do "Romance d'A Pedra do Reino", pg. 285. Quanto ao problema do tempo que ele acrescenta à narração, como eu cortei a alusão desnecessária a "Romeu e Julieta", na pg. 10, uma compensa a outra. Aliás a de "Romeu e Julieta é até maior. (tal rasura consta no verso da página 20 da

${ }^{39}$ GRÉSILlON, Almuth. Devagar: obras. In: ZulAR, Roberto (Org.). Criação em processo: ensaios de crítica genética. São Paulo: Iluminuras, FAPESP, 2002. p. 171.

${ }^{40}$ Ibidem, p. 173.

${ }^{41}$ BIASI. Pierre-Marc de. A genética dos textos. Porto Alegre: EDIPUCRS, 2010. p. 71. 
datiloscópia). Intervenção na forma como a música deve ser cantada. Logo, intervenção na encenação: "Existe música para estes versos de 1930, e eles devem ser cantados com ela." (comentário presente no verso da página 35 do documento).

Como vimos, ao assumir a função de leitor Ariano Suassuna começa um processo de corte, enxerto, sutura e acomodação. Como em uma cirurgia. No momento em que Ariano insere apontamentos ele termina por assumir também a função de comentarista. E como "leitor-cirurgião" e como "leitor-comentarista" Ariano insere a sua vontade autoral não só enquanto autor do texto adaptado para a cena, mas também como encenador interferindo na encenação.

Nesse sentido, a rasura é uma espécie de testemunha de um processo de vida e morte no qual trechos são suprimidos para que um novo conjunto de palavras venha a habitar na página. Contudo, antes de seu efeito final de substituição e/ou eliminação, a rasura, qualquer que seja a sua configuração, abre um momento: momento em que o leitor-escritor se coloca como autor. Nesse sentido, as rasuras seriam componentes desse espaço dialógico da crítica genética em que vários registros distintos como anotações, diários, correspondências e rascunhos, por exemplo, oferecem informações ou pistas sobre o processo criador.

\section{Correspondências: memórias em diálogo}

As cartas tomadas como documentos do arquivo de criação tornam-se o lugar ou o objeto nos quais se encontram vestígios da gênese e das etapas de elaboração de uma obra artística. Segundo Pierre-Marc de Biasi, a proposta da crítica genética ao propor o conhecimento dos textos à luz de seus manuscritos estaria deslocando a interrogação crítica do autor para o escritor, do escrito para a escritura, da estrutura para os processos e da obra para a sua gênese. Para o teórico, "a crítica genética toma por objeto essa dimensão temporal do devir-texto, colocando como hipótese que a obra, na sua perfeição final, conserva o efeito de suas metamorfoses e contém a memória de sua própria gênese." ${ }^{42}$ E por conter essa memória da própria gênese os documentos constituem-se como arquivos - no sentido de que eles seriam os guardiões de um processo criativo. Tais documentos não só guardam como preservam uma memória.

Silviano Santiago, no texto "Com quantos paus se faz uma canoa", presente no livro Arquivos Literários, esclarece:

anotações de leitura, rascunhos, borrões de palavras e frases, acréscimos, resumos, páginas abandonadas, versões negligenciadas etc. etc. todos esses textos nos colocam de imediato no terreno pedregoso em que se misturam lembrança, esquecimento e amnésia. ${ }^{43}$

Nesse sentido, Reinaldo Marques ${ }^{44}$ ao dissertar sobre o arquivamento do escritor observa que se trata de uma dupla operação de arquivamento, pois o escritor executa uma série de práticas arquivísticas que terminam por

\footnotetext{
${ }^{42}$ BIASI. Pierre-Marc de. op. cit, p. 13.

43 Santiago, Silviano. Com quantos paus de faz uma canoa. In: SouZA, Eneida Maria de e MirandA, Wander Mello (orgs.). Arquivos Literários. São Paulo: Ateliê Cultural, 2003. p. 15.

44 Marques, Reinaldo. O arquivamento do escritor. In: SouZA, Eneida Maria de. MirandA, Wander Mello (Orgs.).
} Arquivos Literários. São Paulo: Ateliê Editorial, 2003. p. 141-156. 
construir a sua imagem de autor, preservando assim a memória de sua formação e de suas relações afetivas e intelectuais. Nessa perspectiva, Philippe Artières em seu artigo “Arquivar a própria vida” explica que,

dessas práticas de arquivamento do eu se destaca o que poderíamos chamar uma intenção autobiográfica. Em outras palavras, o caráter normativo e o processo de objetivação e sujeição que poderiam aparecer a princípio, cedem na verdade o lugar a um movimento de subjetivação. Escrever um diário, guardar papéis, assim como escrever uma autobiografia, são práticas que participam mais daquilo que Foucault chamava a preocupação com o eu. ${ }^{45}$

O teórico salienta ainda que "arquivar a própria vida é se por no espelho, é contrapor à imagem social a imagem íntima de si próprio, e nesse sentido o arquivamento do eu é uma prática de construção de si mesmo e de resistência." ${ }^{46} \mathrm{Na}$ sequência, Philippe Artières propõe explorar o arquivamento do eu sob três aspectos: a injunção social, a prática de arquivamento e a intenção autobiográfica. Destaco aqui a prática de arquivamento pensando no aspecto da intenção autobiográfica e o fascínio que tais documentos exercem no pesquisador sedento pelo desvendar dos processos da mente criadora.

E dentro de um arquivo, nada mais fascinante que o acesso à correspondência, essa instância testemunhal de caráter biográfico que nos permite tomar contato com os bastidores de um determinado episódio do processo de criação artística. Segundo José-Luis Diaz

para críticos voyeurs que somos, um dos principais usos das correspondências de escritores é servir comumente para acompanhar os diversos estados de criação de uma obra particular. Úteis aos biógrafos, que querem se assegurar de um fato ou que procuram o "homem" por detrás de seus rascunhos, úteis aos bisbilhoteiros históricos em busca de informações, as cartas sempre foram resguardadas como preciosos arquivos da criação. ${ }^{47}$

No caso desse trabalho, é preciso esclarecer que não há (ou não foi possível ter acesso) um diálogo epistolar entre Ariano Suassuna e Antunes Filho. Ilka Marinho Andrade Zanotto e Sábato Magaldi serviram como intermediários no diálogo entre os dois. Como se trata da gênese de um processo de Antunes é curioso perceber na carta de Ariano, endereçada à Ilka, a sua vontade autoral que autoriza a montagem só que em determinadas condições descritas minuciosamente. E não há uma resposta de Antunes a essa carta. Sabe-se que a peça não foi montada naquela época, mas a resposta de Antunes não está documentada. E é nessas lacunas, nesses vazios que o crítico também se insere. Cabe ao pesquisador trabalhar com o material e com o imaterial: com a presença e a ausência. Ou como observa José-Luis Diaz, "o geneticista é obrigado a se alimentar apenas dos aromas."48

${ }^{45}$ ARTIÈRES, Philippe. Arquivar a própria vida. Revista Estudos históricos. Rio de Janeiro, v.11, n.21, p. 11, 1998. Disponível em: http://bibliotecadigital.fgv.br/ojs/index.php/reh/article/view/2061/1200. Acesso em: 5 set. 2020.

${ }^{46}$ Ibidem, p. 11.

${ }^{47}$ DIAZ, José-Luis. Qual genética para as correspondências? Manuscrítica: Revista de Crítica Genética, São Paulo, n. 15, p. 123, 2007. Disponível em: http://revistas.fflch.usp.br/manuscritica/article/download/1059/967. Acesso em: 13 jul. 2020.

48 Ibidem, p. 128. 
Aromas, visto que o geneticista muitas vezes, na ausência de mais fontes, procura tirar conclusões daquilo que emana do interior dos arquivos. A volatilidade dessas conclusões é algo corriqueiro no processo, visto que o acesso a um novo dado, antes ausente, pode mudar toda a perspectiva da interpretação dos documentos.

\section{Considerações finais}

O dissenso da primeira tentativa de acordo para a realização da montagem, cujo registro se deu através das cartas, depoimentos e rasuras de Ariano, fez com que fosse possível compreender o pensamento do escritor, naquela ocasião, diante de processos adaptatórios. No entanto, é importante esclarecer que a falta de registros provenientes de Antunes Filho nesse primeiro momento, não impediu a discussão sobre o assunto. Assim sendo, não cabe discorrer sobre o que teria sido se... E sim sobre o que foi: o processo de teatralização.

O vasto material genético possibilitou a compreensão desse processo iniciado com um calhamaço, construído por recortes das obras, que foram sendo mesclados com trechos datilografados e manuscritos até dar luz a um sucinto texto teatral de 26 páginas. Tal processo de adaptação foi feito de forma coletiva por uma equipe de atores. No início da década de 1980 um grupo ficara responsável por tal adaptação. Para o espetáculo que estreou em 2006 o ator Lee Taylor foi enxugando alguns trechos da última versão da década de 1980 (revisada por Ariano Suassuna) a fim de dinamizar a sua atuação.

$\mathrm{O}$ acesso a essas indas e vindas e aos vestígios do processo de teatralização de A Pedra do Reino permitiram que eu penetrasse no terreno da intimidade dos bastidores da criação. Sob a forma de cartas, rascunhos, anotações, registros gráficos e declarações diversas que constituíram a memória da obra, foi possível percorrer os traços que integram o arquivo da obra desde sua gênese.

Tomar conhecimento da gênese de A Pedra do Reino implicou em acompanhar suas correções, suas supressões, seus acréscimos e seus vazios. O privilégio de ter tido acesso não só a gênese textual do processo adaptatório, como também da encenação, efetivamente, foi fundamental para compreender os estágios necessários para a operação teatralizadora que se deu primeiramente pela passagem do texto narrativo para o texto dramático e deste para o texto cênico ou o espetáculo em si.

\section{Referências}

AGÊNCIA Estado. Mestres na difícil ciência de decifrar o Brasil. São Paulo, 2006. Entrevista com Ariano Suassuna e Antunes Filho. Disponível em: http://www.nordesteweb.com/not07_0906/ne_not_20060720b.htm. Acesso em: 06 jun. 2020.

Andrade, Lucimara de. Pelo viés da teatralização: A Pedra do Reino por Antunes Filho. 2017. Tese (Doutorado em Estudos Literários) Faculdade de Letras, Universidade Federal de Minas Gerais, Belo Horizonte, 2017. Disponível em: https://repositorio.ufmg.br/handle/1843/LETR-AMHG8D. Acesso em: 20 nov. 2020.

ARTIÈRES, Philippe. Arquivar a própria vida. Revista Estudos históricos. Rio de Janeiro, v.11, n.21, p. 9-34, 1998. Disponível em: http://bibliotecadigital.fgv.br/ojs/index.php/reh/article/view/2061/1200. Acesso em: 5 set. 2020.

Benjamin, Walter. Escavando e recordando. In: Obras Escolhidas. Rua de Mão Única. São Paulo: Brasiliense, 1995. p. 239-240. 
Berthold, Margot. Teatro do diretor. In: História mundial do Teatro. São Paulo: Perspectiva. 2006. p. 529-539.

BIASI. Pierre-Marc de. A genética dos textos. Porto Alegre: EDIPUCRS, 2010.

BUTOR, Michel. Crítica e Invenção. In: BUTOR, Michel. Repertório. São Paulo: Perspectiva, 1974. p. 191-203.

CAmpos, Haroldo de. In: TÁpIA, Marcelo e Nóbrega Thelma Médici (Orgs.). Haroldo de Campos -

Transcrição. São Paulo: Perspectiva. 2013.

CAmpos, Maximiano. A Pedra do Reino. In: SuAssuna, Ariano Villar. Romance d'A Pedra do Reino e o príncipe do sangue do vai-e-volta. Rio de Janeiro: José Olympio Editora, 2006. p. 745-754.

CARLSON, Marvin. Teorias do teatro: estudo histórico-crítico, dos gregos à atualidade. São Paulo: Editora UNESP, 1997.

DE MARINIS, Marco. Nova teatrologia e performance studies: questões para um diálogo. Repertório: teatro \& dança, Salvador, ano 13, n. 15, p. 95-103, 2010.

DIAZ, José-Luis. Qual genética para as correspondências? In: Manuscrítica - Revista de Crítica Genética, São Paulo, n. 15, p. 119-162, 2007.

FOCILlON, Henri. Elogio da mão. In: FoCILlON, Henri. Vida das formas. Rio de Janeiro: Zahar, 1983. p. 126-156. GRÉSILLON, Almuth. Devagar: obras. In: ZULAR, Roberto (Org.). Criação em processo: ensaios de crítica genética. São Paulo: Iluminuras, FAPESP, 2002. p. 147-174.

HAY, Louis. A literatura dos escritores. Belo Horizonte: Editora UFMG, 2007.

JAKOBSON, Roman. Os aspectos linguísticos da tradução. In: JAKOBSON, Roman. Linguística e comunicação. São Paulo: Cultrix, 1995. p. 63-72.

LEBRAVE, Jean-Louis. Crítica genética: uma nova disciplina ou um avatar moderno da filologia? In: ZULAR, Roberto (Org.). Criação em processo: ensaios de crítica genética. São Paulo: Iluminuras, Fapesp, 2002. p. 97-146. MARQUeS, Reinaldo. O arquivamento do escritor. In: SouZA, Eneida Maria de. MirandA, Wander Mello (orgs.). Arquivos Literários. São Paulo: Ateliê Editorial, 2003. p. 141-156.

MeNCARELli. Fernando Antonio. Dramaturgias em processo: a cena pelo avesso. In: GRUPO TeAtro INVERTIDO. Cena invertida: dramaturgias em processo. Belo Horizonte: Edições CPMT, 2010. p. 12-25.

MILARÉ, Sebastião. Hierofania: o teatro segundo Antunes Filho. São Paulo: Edições SESC SP, 2010.

PAVIS, Patrice. Dicionário de teatro. São Paulo: Perspectiva, 2015.

RYNGAERT, Jean-Pierre. Ler o teatro contemporâneo. São Paulo: Martins Fontes, 1998.

SALLES, Cecilia Almeida. Gesto inacabado: processo de criação artística. São Paulo: FAPESP: Annablume, 1998. SANTIAGo, Silviano. Com quantos paus de faz uma canoa. In: SouZA, Eneida Maria de e MiRANDA, Wander Mello (orgs.). Arquivos Literários. São Paulo: Ateliê Cultural, 2003. p. 15-24.

SANTINI, Alexandre. Teatro e cultura brasileira no século 20 - Ariano Suassuna e Movimento Armorial.in: RABETTI, Beti (Org.). Teatro e comicidades: estudos sobre Ariano Suassuna e outros ensaios. Rio de Janeiro: 7Letras, 2005. p. 63-69.

SuAssuna, Ariano Villar. Entrevista sem título. In: BACCARELli, Milton. O Teatro em Pernambuco: trocando a máscara. Recife: FUNDARPE, 1994. p. 142-146.

TÁPIA, Marcelo. Apresentação. In: TÁPIA, Marcelo e NÓBREGA Thelma Médici (Orgs.). Haroldo de Campos Transcrição. São Paulo: Perspectiva. 2013. p. XI-XX. 
Trotta, Rosyane. Autoralidade, grupo e encenação. Sala Preta, São Paulo, vol. 6, 2006. Disponível em: http://www.revistas.usp.br/salapreta/article/view/57305. Acesso em: 3 ago. 2020.

Ubersfeld, Anne. Para ler o teatro. São Paulo: Perspectiva, 2005.

Willemart, Philippe. A rasura e a consistência. In: WILlEMART, Philippe. Universo da criação literária: crítica genética, crítica pós-moderna? São Paulo: Editora da Universidade de São Paulo, 1993. p. 67-73.

ZanotTo. Ilka Marinho de Andrade. Quaderna. Sala Preta, São Paulo, n. 6, p. 97-102, 2006.

\section{Referências audiovisuais:}

SuASSUNA, Ariano Villar. São Paulo, Brasil, 15 jun. 2007. 1DVD. Entrevista concedida ao Programa Metrópolis. 